\title{
EKSISTENSI KAUM DIFABEL DALAM PERSPEKTIF AL-QUR'AN
}

\author{
Khairunnas Jamal, Nasrul Fatah, dan Wilaela \\ Universitas Islam Negeri Sultan Syarif Kasim Riau, Indonesia \\ khairunnas.jamal@uin-suska.ac.id
}

\begin{abstract}
The existence of disabled people can not be denied and is a part of human life. Based on the theory of social science in general, people with disabilities can be grouped into three, namely physical, non-physical and dual. All this group of disabilities leads to the inability and malfunction of the physical organs (senses) and non-physical. At the level of reality, people with disabilities still often get discrimination and negative stigma from some parties. This paper seeks to see how the Qur'an speaks of the disabled and its existence in the legal and social order. The terminology used by the Qur'an to show the existence of the disabled is a'ma, akmah, bukm, and shum. There are 38 verses scattered in 26 letters in the Qur'an. Of these, there are only five verses that speak of physical disability and the rest speak of non-physical deformities. From this paper it can be seen that people with disabilities according to the Qur'an people who have physical and theological disability. In terms of its existence, they are the same as other normal individuals in both legal and social aspects. Although in some cases and conditions have the specificity as a form of protection.
\end{abstract}

Keywords: Disabled People, existence, and al-Qur'an.

\begin{abstract}
Abstrak
Keberadaan kaum penyandang cacat tidak dapat dinafikan dan merupakan bagian dari kehidupan menusia. Berdasarkan teori ilmu sosial secara umum penyandang cacat dapat dikelompokkan menjadi tiga, yaitu fisik, non fisik, dan ganda. Semua kelompok penyandang cacat ini bermuara kepada ketidakmampuan dan tidak berfungsinya organ-organ fisik (panca indra) maupun non fisik. Pada tataran realita para penyandang cacat masih sering mendapatkan perlakuan diskriminasi dan stigma negatif dari beberapa pihak. Tulisan ini berusaha untuk melihat bagaimana al-Qur'an berbicara mengenai penyandang cacat serta eksistensinya dalam tatanan hukum dan sosial. Terminologi yang digunakan al-Qur'an untuk menunjukkan keberadaan penyandang cacat adalah adalah a'ma, akmah, bukm, dan shum. Terdapat 38 ayat yang tersebar dalam 26 surat dalam al-Qur'an. Dari jumlah yang cukup banyak tersebut hanya ada lima ayat yang berbicara mengenai cacat fisik dan selebihnya berbicara mengetani cacat non fisik. Dari tulisan ini dapat diketahui bahwa penyandang cacat menurut al-Qur'an orang yang memiliki kecacatan fisik dan teologis. Dari segi keberadaannya, mereka adalah sama dengan individu normal lainnya, baik dalam aspek hukum maupun sosial. Meskipun dalam beberapa hal dan kondisi memiliki kekhususan sebagai bentuk perlindungan.
\end{abstract}

Kata Kunci: Kaum Difabel, Eksistensi, dan al-Qur'an. 


\section{Pendahuluan}

Panca indra merupakan bagian yang sangat penting dalam diri manusia. Hal itu disebabkan karena ia bagaikan jendela bagi jiwa, di mana melaluinya gambaran-gambaran, konsep atau pengetahuan mengenai suatu objek eksternal masuk ke dalam pikiran manusia. ${ }^{1}$ Sedangkan kenyataan menunjukkan bahwa di antara manusia ada yang diciptakan Allah dalam keadaan yang berbeda, baik fisik maupun non fisiknya, yang kemudian disebut dengan cacat.

Penyandang cacat, disabilitas dan difabel adalah beberapa istilah yang dilabelkan kepada individu yang memiliki kondisi dan kemampuan berbeda dengan individu normal, terutama pada kemampuan fisik. ${ }^{2}$ Diskusi akademisi mengenai kelompok ini bisa dikatakan mulai muncul pada beberapa dasawarsa terakhir, seiring dengan maraknya perbincangan mengenai wawasan mutikultural di Indonesia. Salah satu segmen multikulturalisme adalah wawasan mengenai penyandang cacat sebagai bagian dari penghargaan terhadap kelompok yang memiliki kondisi fisik berbeda dengan kebanyakan.

Penyandang difabel, dalam kajian ilmu sosial secara umum merupakan sebutan untuk merujuk kepada mereka yang memiliki kelainan fisik atau non-fisik. Secara umum, difabel dapat dibedakan menjadi tiga jenis, yaitu: (1) kelompok kelainan secara fisik, terdiri dari tunanetra, tunadaksa, tunarungu, dan tunarungu wicara, (2) kelompok kelainan secara non-fisik, terdiri dari tunagrahita, tunalaras dan autis, dan (3) kelompok kelainan ganda, yaitu mereka yang mengalami kelainan lebih dari satu jenis kelainan. ${ }^{3}$

${ }^{1}$ Kadar M. Yusuf, "Indera Manusia Menurut al-Qur'an dan Psikologi; Suatu Kajian Perbandingan" (Laporan Penelitian: Universitas Negeri Sultan Syarif Kasim Riau, 2003), 6.

${ }^{2}$ Nur Khalis Setiawan, Pribumisasi al- Qur'an (Yogyakarta: Kaukaba, 2012), 75.

${ }^{3}$ Akhmad Sholeh, "Islam dan Penyandang Disabilitas: Telaah Hak Aksesibilitas Penyandang Disabilitas dalam Sistem Pendidikan di Indonesia", Jurnal PALASTREN 8, no. 2 (2015): 303. Lihat juga Frieda Mangunsong, Psikologi dan Pendidikan Anak Berkebutuhan Khusus, jilid 1dan II (Depok: LPSP3 UI, 2011).
Diskusi mengenai keberadaan kelompok difabel berangkat dari kenyataan bahwa jumlah mereka yang relatif banyak. Kajian mengenai keberadaan kelompok ini menjadi penting mengingat jumlah mereka yang cukup besar. Berdasarkan data Data dari Badan Kesehatan Dunia (WHO), Bank Dunia dan International Labour Organization (ILO) mencatat, jumlah kelompok difabel saat ini sekitar 15 persen dari populasi dunia atau sebanyak satu milyar orang. Sementara paling sedikit terdapat 785 juta penyandang cacat masuk dalam usia kerja. Di Indonesia sendiri, berdasarkan data Pusdatin Kemensos sampai tahun 2010 jumlah penyandang difabel mencapai 11.580.117. ${ }^{4}$

Di sisi lain, kenyataannya tidak sedikit para penyandang difabel yang menerima perlakuan tidak menyenangkan, stigma negatif serta stereotip ${ }^{5}$ dari orang-orang sekitar. Berbagai bentuk diskriminasi pun kerapkali dialamatkan kepada mereka, mulai dari bulliying, dikucilkan, rendahnya pendidikan serta minimnya lapangan pekerjaan. Meskipun pada tatanan global, sudah mulai muncul kepedulian terhadap kelompok ini. Hal ini ditandai dengan ditetapkannya tanggal 3 Desember sebagai Hari Penyandang Cacat Sedunia, akan tetapi nampak belum tersosialisasi dengan baik sehingga belum diketahui orang luas. Prihatinnya lagi, praktik-praktik tidak menyenangkan terhadap penyandang difabel juga dapat dilakukan di lingkungan akademik yang seharusnya menjadi 'lingkungan garis depan' yang mengkampanyekan ramah difabel.

Kemudian, sebagai bangsa yang mayoritas penduduknya beragama Islam, bahkan menempati jumlah muslim terbesar di dunia, kajian tentang keberadaan kaum cacat ini perlu dilihat dalam perspektifal-Qur'an sebagai kitab suci umat Islam.

\footnotetext{
${ }^{4} \mathrm{http}: / / \mathrm{m}$. liputan6.com diakses pada 25 Juli 2016. Lihat juga Poskota News.com diakses pada 25 Juli 2016.

${ }^{5}$ Stereotip adalah konsepsi mengenai sifat suatu golongan berdasarkan prasangka yang subjektif dan tidak tepat, atau dengan kata lain sebuah bentuk pelabelan dan pandangan tidak baik kepada seseorang atau kelompok. Pusat Bahasa, Kamus Bahasa Indonesia (Jakarta: DEPDIKNAS, 2008), 1376.
} 
Sehingga diharapkan dapat memberi sumbangsih bagi peletakan dasar-dasar teologis dalam upaya memposisikan keberadaan penyandang cacat sebagaimana seharusnya.

\section{Pengertian Difabel}

Difabel, berasal dari Bahasa Inggris, difable (differently able, different ability, differently abled people) yang berarti orang dengan kemampuan yang berbeda. Dalam Kamus Bahasa Indonesia, difabel juga berarti penyandang cacat. ${ }^{6}$ Maka dapat dipahami istilah ini adalah sebutan lain untuk menunjukkan penyandang cacat. Istilah ini diperkenalkan secara substansi untuk mengganti penggunaan istilah disabilitas, di mana kosa kata tesebut dianggap diskriminatif dan mengandung stigma negatif terhadap para penyandang cacat oleh aktivis gerakan sosial di tahun 1990-an. Istilah ini dipopulerkan oleh Mansour Fakih seorang aktivis pada tahun 1995 dalam pengertian kemampuan fisik yang berbeda. ${ }^{7}$

Dengan demikian, penggunaan istilah difabel adalah sebuah usaha untuk menghapus pandangan terhadap para penyandang cacat yang seolah tidak dibutuhkan atau hanya menyusahkan orang lain saja.

\section{Metamorfosis Istilah Difabel}

Ada cukup banyak istilah lain yang digunakan untuk menyebutkan penyandang difabel, dan masing-masing memiliki kepentingan ideologis tersendiri serta berbagai pertimbangan penggunaannya, yaitu:

Penyandang cacat, terdiri dari dua kata, yaitu penyandang dan cacat. Menurut Kamus Bahasa Indonesia, kata penyandang berasal dari kata sandang yang memiliki arti orang yang menderita. ${ }^{8}$ Sedangkan kata cacat berarti kekurangan yang menyebabkan nilai atau mutunya kurang baik atau kurang sempurna (yang terdapat pada badan,

\footnotetext{
${ }^{6}$ Pusat Bahasa, 353.

${ }^{7}$ Mansour Fakih, Kesetaraan Hak Penyandang Cacat (Yogyakarta: Kaukaba, 2004), 168-169.

${ }^{8}$ Pusat Bahasa, 1259.
}

benda, batin, atau akhlak); lecet (kerusakan, noda) yang menyebabkan keadaannya menjadi kurang baik (kurang sempurna); cela; aib; tidak (kurang) sempurna. ${ }^{9}$

Undang-Undang RI Nomor 4 Tahun 1997 tentang Penyandang Cacat, Pasal 1 Ayat 1, mendefinisikan 'penyandang cacat' sebagai "setiap orang yang mempunyai kelainan fisik atau mental, yang dapat mengganggu atau merupakan rintangan dan hambatan baginya untuk melakukan kegiatan secara selayaknya." Definisi ini nampaknya cukup representatif untuk menggambarkan persepsi masyarakat secara umum terhadap pengertian dan keadaan penyandang cacat.

Penyandang ketunaan, berasal dari kata "tuna", yaitu dari bahasa Jawa Kuno yang berarti rusak atau rugi. Kamus Bahasa Indonesia mengartikan kata "tuna" dengan luka; rusak; kurang; tidak memiliki. ${ }^{10}$ Penggunaan kata ini diperkenalkan pada awal tahun 1960-an sebagai bagian dari istilah yang mengacu pada kekurangan yang dialami oleh seseorang pada fungsi organ tubuhnya secara spesifik, misalnya istilah tunanetra, tunarungu, tunadaksa, dan tunagrahita.

Penggunaan istilah "tuna" ini pada awalnya dimaksudkan untuk memperhalus kata cacat demi tetap menghormati martabat penyandangnya, tetapi dalam perkembangan selanjutnya kata tuna digunakan juga untuk membentuk istilah yang mengacu pada kekurangan non-organik, misalnya istilah tunawisma, tunasusila, dan tunalaras. ${ }^{11}$

Orang berkebutuhan khusus (person with special needs), memiliki pengertian yang sangat luas. Menurut Frieda Mangunsong, orang berkebutuhan khusus dapat diartikan sebagai "orang yang secara signifikan berbeda dimensi yang penting dari fungsi kemanusiaannya. Mereka yang secara fisik, psikologis, kognitif atau sosial terhambat dalam mencapai tujuan-

\footnotetext{
${ }^{9}$ Ibid., 249.

${ }^{10}$ Ibid., 1563.

${ }^{11}$ Akhmad Sholeh, 300.
} 
tujuan atau kebutuhan dan potensinya secara maksimal, meliputi tuli, buta, mempunyai gangguan bicara, cacat tubuh, retradasi mental, dan gangguan emosional. Juga mereka yang berbakat dengan intelegensi yang tinggi dapat dikategorikan sebagai orang berkebutuhan khusus atau luar biasa, karena memerlukan penanganan yang terlatih dari tenaga profesional. ${ }^{12}$ Dengan demikian, penggunaan istilah ini lebih luas cakupannya, yaitu seluruh orang yang memiliki penanganan dan pelayanan khusus, baik berupa kekurangan maupun kelebihan. Selain itu, istilah ini lebih banyak digunakan dalam bidang kependidikan.

Disabilitas, berasal dari Bahasa Inggris dis able, disability yang memiliki arti ketidakmampuan. The Social Work Dictionary mendefinisikan disability dengan reduksi fungsi secara permanen atau temporer serta ketidakmampuan seseorang untuk melakukan sesuatu yang mampu dilakukan oleh orang lain sebagai akibat dari kecacatan fisik atau mental. ${ }^{13}$

Penggunaaan istilah ini menunjukkan konsekuensi fungsional dari kerusakan bagian tubuh seseorang. Misalnya, seseorang yang pertumbuhan tulang kakinya menjadi tidak normal akibat terjangkit penyakit polio. Untuk selanjutnya ia tidak dapat beraktivitas leluasa apabila tidak dibantu dengan alat penunjang khusus, seperti kruk kursi roda atau kaki palsu.

Setelah melihat berbagai istilah yang digunakan untuk mendenotasi penyandang cacat, nampak masing-masing istilah itu membawa nilai ideologis tersendiri. Meski demikian, kesemuanya itu menunjuk pada suatu kesimpulan yang sama, bahwa penyandang cacat adalah seorang yang potensial bermasalah. Maksudnya, para penyandang cacat memiliki peluang yang sangat besar untuk menemui masalah dan kesulitan dalam hidupnya. Sehingga yang diperlukan oleh

${ }^{12}$ Dewi Pandji, Sudahkah Kita Ramah Pada Anak Special Needs? (Jakarta: PT Elex Media Komputindo, 2013), 2.

${ }^{13}$ Nur Kholis Setiawan, 68; Lihat juga Husamah, A to Z Kamus Psikologi Super Lengkap (Yogyakarta: Andi Offset, 2015), 83. mereka adalah adanya cara pandang, perlakuan, pelayanan, dan informasi yang tepat. Sebab jika mereka mendapatkan semua itu potensi mereka dapat berkembang secara optimal.

\section{Terminologi Difabel Dalam al-Qur'an}

Secara eksplisit tidak ditemukan term dalam al-Qur'an yang menunjukkan makna cacat, melainkan hanya ditemukan beberapa term yang memberikan indikasi makna bagian dari kategori penyandang difabel. Dengan bantuan aplikasi al-Qur'an digital dengan menginput kosa kata beberapa kategori penyandang cacat, yaitu buta, tuli, bisu, dan pincang, didapat informasi bahwa dalam al-Qur'an digunakan beberapa kata untuk menunjukkan penyandang

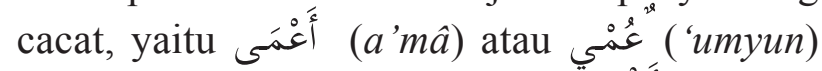
dan berbagai derivasinya serta أَكْكَّنَ (akmah) untuk menunjukkan makna buta (tunanetra), بُخْ (bukmun) dan derivasinya untuk menunjukkan makna bisu (tunawicara), صصّم (shummun) dan derivasinya untuk menunjukkan makna tuli (tunarungu), dan أَعْرَ (a raj) untuk menunjukkan makna pincang (bagian dari tunadaksa). ${ }^{14}$

Pertama, kata عُعَْ أَعْمَى (a'mâ) atau ('umyun). Secara literal kata عَعَ' (a'mâ) atau عُمْني ('umyun) ini berasal dari mufradat bahasa Ärab dalam bentuk fi'il (kata kerja) عَمَ' (fi'il mâdhi), يَ (fi'il mudhâri'), sedangkan bentuk

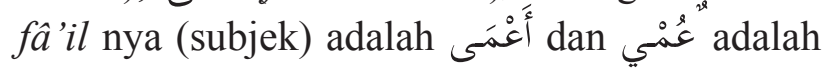
bentuk mashdar nya (infinitive), di mana kosa kata ini memiliki makna hilangnya seluruh pengelihatan. ${ }^{15}$ Pengertian ini sesuai dengan kata 'buta atau tunanetra' dalam bahasa Indonesia. Sedangkan dalam Kamus Mushthalahât al 'Ulum al Ijtimâ'iyah al Injiliziy wa al 'Arabiy, kata a'ma berarti suatu keadaan terhambatnya pengelihatan yang mencakup kebutaan total maupun keadaankeadaan lain yang mendekatinya, yang dalam

\footnotetext{
${ }^{14}$ Ayat Aplikasi al-Qur'an Digital dan al- Qur'an digital versi 1.3.4.

${ }^{15}$ Ibnu Mazhûr, Lisân al- 'Arab, jilid 4 (Beirut: Dâr Shâdir, 2010), 3115 .
} 
bahasa Inggris disebut blindness. ${ }^{16}$

Berdasarkan hasil penelusuran Mu'jam al Mufahras li Alfâzh al-Qur'ân al Karîm, kata 'أ (a'mâ) terulang sebanyak 33 kali dalam 30 ayat serta tersebar dalam 21 surat. Sebaran ayat-ayat tersebut adalah al-Baqarah [2]: 18, 171, al-Mâidah [5]: 71, al-An'âm [6]: 104, 50, al-A'râf [7]: 64, Yunus [10]: 43, Hud [11]: 24, 28, al-Qashash [28]: 66, al Ra'd [13]: 16, 19, alIsra' [17]: 73, 97, al-Hajj [22]: 46, Thâha [20]: 124, 125, al-Nûr [24]: 61, al-Furqân [25]: 73, alNaml [27]: 66, 81, al-Rûm [30]: 53, Fâthir [35]: 19, al Ghâfir [40]: 58, al Fushilat [41]: 17, alZukhrûf [43]: 40, Muhammad [47]: 23, al-Fath [48]: 17, 'Abasa [80]: $2 .{ }^{17}$

Kedua, kata أكْمَ (akmah). Menurut asal katanya, أَخَّْ (akmah) ini terambil dari kata yang dalam kamus Lisan al 'Arab diartikan keadaan buta pada seseorang sejak kelahirannya. Selain itu, menurut Ibnu al-A'rabiy, kata آكْحَ (akmah) berarti seseorang yang dapat melihat di waktu siang, namun tidak dapat melihat di waktu malam. ${ }^{18}$ Dengan demikian, dilihat dari pengertian tersebut, kosa kata أَكْمَـ (akmah) sesuai jika dikategorikan untuk mewakili salah satu bagian dari tunanetra tidak total yang disebut dengan low vision. Penggunaan kata أَكَمَه (akmah) terulang sebanyak 2 kali yang tersebar dalam 2 surat, yaitu pada surat Ali 'Imrân [3]:49 dan al- Mâidah [5]: $110 .^{19}$

Ketiga, kata بُ بُ (bukmun). Menurut asal lughatnya, بَبْ (bukmun) berasal dari kata

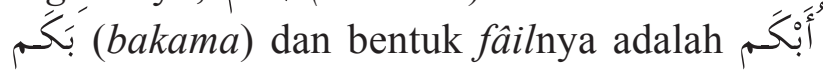
(abkamu) memiliki arti yang dekat dengan makna kata أَخْنَس (al kharasu) atau bisu (tunawicara). ${ }^{20}$ Hanya antara kata بُخْمَ (bukmun) dan (al-

\footnotetext{
${ }^{16}$ Muslih al-Shâlih, Qâmûs Musthalahât al- 'Ulum al-Ijtimâ'iyah Injilizî wa al- 'Arabî (Riyâdh: Dâr al- 'Alam al-Kutub, 1419 H), 69.

${ }^{17}$ Muhammad Fuad 'Abd al-Bâqi, al- Mu'jam al-Mufahras li Alfâzh al-Qur'ân al- Karîm (Kairo: Dâr al-Hadîts, 1364 H), 488489.

${ }^{18}$ Ibnu Mazhûr, Lisan al- 'Arab, jilid 5, 3933; Lihat juga Ahmad Warson Munawir, Kamus al-Munawwir, cet. 25 (Surabaya: Pustaka Progresif, 2002), 1231.

${ }^{19}$ Muhammad Fuad 'Abd al-Bâqi, 621.

${ }^{20} \mathrm{Ahmad}$ Warson Muanwwir, 331.
}

kharasu) terdapat perbedaan pada penggunaannya menurut Kalam al- 'Arab, di mana kata الَخَـَرَس (al-kharasu) lebih tepat dan biasanya digunakan untuk menunjukkan makna sesuatu yang memang diciptakan tanpa kemampuan berbicara seperti binatang. Sedangkan بُ (bukmun) lebih digunakan untuk sesuatu yang diciptakan pada umumnya dapat berbicara, namun pada orang itu (penderitanya) tidak memiliki kemampuan berkata-kata. ${ }^{21}$ Kata بُ (bukmun) dan derivasinya dalam al-Qur'an terulang sebanyak 6 kali yang tersebar dalam 5 surat, yaitu pada surat al-Baqarah [2]: 18, 171, al-An'âm [6]: 39, al- Anfâl [8]: 33, al-Nahl [16]: 76 dan al-Isra' [17]: 97.22

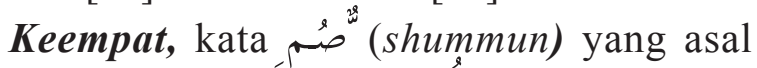

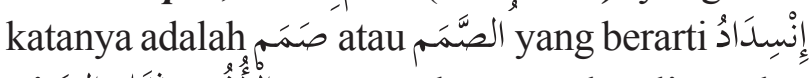

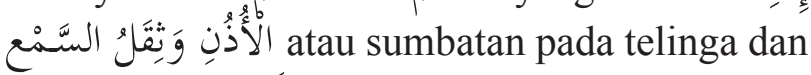
kesulitan/ganggúan mendengar. ${ }^{23}$

Kata صَّم: (shummun) dan berbagai derivasinya di dalam al-Qur'an terulang sebanyak 15 kali dalam 14 ayat dan tersebar dalam 13 surat, yaitu: al-Baqarah [2]: 18, 171, al-Mâidah [5]: 71, alAn'âm [6]: 39, al-Anfâl [8]: 22, Yûnus [10]: 42, Hûd [11]: 24, al-Isrâ' [17]: 97, al-Anbiyâ' [21]: 45, al-Furqân [25]: 73, al-Naml [27]: 70, al-Rûm [30]: 52, al-Zukhrûf [43]: 40, dan Muhammad [47]: 23. ${ }^{24}$

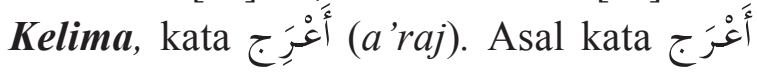
(a'raj) adalah عَرَّرَ ('araja) yang berarti naik

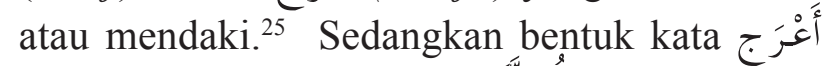
(a'raj) memiliki makna الظَّكَع yaitu pincang dan timpang, ${ }^{26}$ hal ini dikarenakan seorang yang pincang kakinya, berjalan seolah sedang menanjak, naik ke tempat yang lebih tinggi atau berjalan pada permukaan yang tidak datar. kata أَعْـرَج (a'raj) dalam al-Qur'an terulang sebanyak 2 kali yang termuat dalam 2 surat, yaitu surat alNûr [24]: 61 dan al-Fath [48]: 17. ${ }^{27}$

\footnotetext{
${ }^{21}$ Ibnu Mazhûr, Lisan al- 'Arab, jilid 1, 337.

${ }^{22}$ Muhammad Fuad 'Abd al-Bâqi, 133.

${ }^{23}$ Ibnu Manzhûr, Lisan al-'Arab, jilid 4, 2500; Lihat juga,

Muhammad Warson Muanwwir, 795.

${ }^{24}$ Muhammad Fuad 'Abd al-Bâqi, 414.

${ }^{25}$ Muhammad Warson Munawwir, 913.

${ }^{26}$ Ibid., 880.

${ }^{27}$ Muhammad Fuad 'Abd al-Bâqi, 456.
} 
Keseluruhan term-term tersebut dapat ditemukan dalam 38 ayat atau sekitar 0,60\% dari keseluruhan ayat al-Qur'an (6236 ayat), ${ }^{28}$ yang tersebar dalam 26 surat atau 22,8\% dari keseluruhan surat dalam al-Qur'an (114 surat), 17 di antaranya adalah surat-surat Makkiyah, sedangkan 9 surat lainnya adalah Madaniyah. Sebaran surat-surat tersebut adalah: 'Abasa $\left(\mathrm{K}^{29} .24^{30}\right)\left[80^{31}\right]$ : 2, al-A'râf(K.39) [7]: 64, al-Furqân (K.42) [25]: 73, Fâthir (K.43) [35]: 19, Thâha (K.45) [20]: 124, 125, al-Naml (K.48) [27]: 66, 80, 81, alQashash (K.49) [28]: 66, al-Isra' (K.50) [17]: 72, 97, Yunus (K.51) [10]: 42, 43, Hud (K.52) [11]: 24, 28, al-An'âm(K.55) [6]: 39, 50, 104, Ghâfir (K.60) [40]: 58, Fushshilat (K.61) [41]: 17, al- Zukhrûf (K.63) [43]: 40, al-Nahl (K.70) [16]: 76, al-Anbiyâ' (K.73) [21]: 45, al-Rûm (K.84) [30]: 52, 53, al-Baqarah $\left(\mathrm{M}^{32} .1^{33}\right)$ [2]: 18, 171, al- Anfâl (M.2) [8]: 22, Ali 'Imrân (M.3) [3]:49, Muhammad (M.9) [47]: 23, al-Ra'd (M.10) [13]: 16, 19, al-Nûr (M.17) [24]: 61, al-Hajj (M.18) [22]: 46, al-Fath (M.26) [48]: 17, dan al-Mâidah (M.27) [5]: 71, 110.

\section{Konotasi Term Difabel dalam al-Qur'an}

Berangkat dari informasi mengenai sebaran term-term penyandang cacat dalam al-Qur'an di atas, didapat bahwa term-term tersebut merujuk

\footnotetext{
${ }^{28}$ Jumlah ini adalah berdasarkan jumlah ayat-ayat yang ditetapkan dalam mushaf al-Qur'an yang digunakan saat ini. Para ulama berbeda pendapat dalam menentukan jumlah ayat al-Qur'an. Sebab-sebab rumusan itu dapat diringkas dalam tiga hal; (1) huruf-huruf hijaiyyah di awal beberapa surat, (2) basmalah, sebagian ulama menghitungnya sebagai sebuah ayat yang independen, dan (3) perbedaaan sahabat nabi ketika mendengarkan bacaaan al-Qur'an Rasul Saw. antara bacaan berhenti karena akhir ayat atau karena waqaf. Menurut Imam Abu Amar al-Dhânî, para ulama menyepakati bilangan 6000 sebagai jumlah ayat al-Qur'an, namun selebihnya mereka berselisih. Lebih lanjut lihat Jalâl al-Dîn al- Suyuthî, AlItqân fî̀ 'Ulûm al-Qur'ân, jilid 1, (Kementrian Agama, Wakaf dan Dakwah Kerajaan Arab Saudi), 187-190; Lihat juga Nur Faizin, Sepuluh Tema Kontroversial 'Ulum alQur'an (Kediri: CV Azhar Risalah, 2011), 10.

${ }^{29}$ Kode surat Makiyah.

${ }^{30}$ Nomor urut surat Makiyah.

${ }^{31}$ Nomor urut surat pada mushaf al-Qur'an.

${ }^{32}$ Kode surat Madaniyah.

${ }^{33}$ Nomor urut surat Madaniyah.
}

pada dua konotasi, yaitu:

1. Konotasi negatif (cacat non fisik)

Term-term penyandang cacat yang termuat dalam ayat-ayat al-Qur'an kebanyakan digunakan dalam konteks tidak baik dan tidak dalam pengertian fisik berupa kecaman dan ancaman balasan bagi orang-orang yang mensekutukan Allah, mengingkari ayatayat-Nya, mendustakan petunjuk anjuran para rasul. Jumlah ayat yang memuat termterm difabel dengan konotasi negatif ini adalah 33 ayat. Penggunaan term-term itu menggambarkan perilaku orang yang tidak beriman, tidak taat, serta tidak mengikuti anjuran berbuat baik. Di samping itu juga digunakan sebagai tamsil kesempurnaan fisik yang tidak memiliki manfaat akibat tidak dipergunakan untuk menelaah dan menerima kebenaran.

Konotasi negatif dari term-term penyandang cacat dalam al-Qur'an tersebut pada umumnya tidak merujuk pada kecacatan fisik, melainkan lebih kepada kecacatan mental berupa kecacatan hati dan teologis dari seseorang. Berikut adalah beberapa karakteristik cacat mental/teologis yang disebutkan dalam al-Qur'an:

a. Mendustakan risalah para nabi, memusuhi bahkan melakukan tindak kekerasan terhadap mereka. Karakteristik seperti ini digambarkan dalam surat al-A'râf (K. 39) [7]: 64, al-Naml (K.48) [27]: 80-81, Fushshilat (K. 61) [41]: 17, al-Zukhrûf (K.63) [43]: 40, al-Rûm (K.84) [30]: 5243, dan al-Mâidah (M.27) [5]: 71.

b. Mendustakan ayat-ayat Allah (kitab suci), mengacuhkannya serta tidak megambil manfaat daripadanya, seperti disebutkan dalam surat: al-Furqân (K.42) [25]: 73, al-An'âm (K.55) [6]: 39, al-Anfâl (M.2) [8]: 22, al- Ra'd (M.10) [13]: 19 dan alHajj (M.18) [22]: 46.

c. Menjadikan sekutu selain Allah SWT, disebutkan dalam surat: al-An'âm (K.55) 
[6]: 50, al-Ra'd (M.10) [13]: 16.

d. Tidak mengambil manfaat dari panca indra untuk menelaah dan menerima kebenaran, seperti ada pada surat: Yûnus (K.51) [10]: 42-43, al-An'âm (K.55) [6]: 104 dan alBaqarah (M.1) [2]: 18, 171.

e. Durhaka, berbuat kerusakan di bumi serta memutus silaturrahim, dalam surat: Fâthir (K.43) [35]:19, Ghâfir (K.60) [40]: 58 dan Muhammad (M.9) [47]: 23.

f. Meningkari hari akhirat dan bentuk balasan di akhirat, dalam surat: Thâha (K.45) [20]: 125, al-Naml (K.48) [27]: 66, al- Qashash (K.49) [28]: 66, dan al- Isrâ' (K.50) [17]: 72.

g. Berpaling dari peringatan Allah dan lalai berzikir kepada-Nya, Thâha (K.45) [20]: 124.

Secara eksplisit redaksi ayat-ayat yang menunjukkan konotasi negatif di atas, memang menggunakan term-term yang ditinjau dari aspek kebahasaan memiliki arti cacat fisik. Meskipun demikian, namun konteks ayat-ayat tersebut tidak dimaksudkan untuk menunjukkan makna kecacatan fisik. Cacat fisik yang dipergunakan al-Qur'an untuk menggambarkan sisi negatif dari individu yang tidak beriman, bisa dikatakan mewakili peradaban Arab pada masa saat wahyu itu diturunkan. Hal ini dikarenakan dalam ilustrasi budaya Arab saat itu, bisu, tuli, dan buta mewakili individu atau kelompok yang secara sosial diasingkan serta dimarjinalkan. Berdasarkan catatan sejarah dan tinjauan antropologis, kehidupan bangsa Arab pra Islam berada pada suatu keadaan yang sangat keras disebabkan perwatakan yang keras dan pemberani hasil bentukan kondisi geografis yang cadas. ${ }^{34}$

Berangkat dari kondisi geografis yang tidak dapat dipungkiri memberi pengaruh besar

\footnotetext{
${ }^{34} \mathrm{Ahmad}$ Syalabi, Sejarah Kebudayaan Islam, jilid. I (Jakarta: al-Husna Zikra, 1997), 34.
}

terhadap psikologis bangsa Arab. Mereka sangat menekankan hubungan kesukuan sehingga kesetiaan atau solidaritas kelompok menjadi kekuatan bagi suatu kabilah ${ }^{35}$ atau suku. Mereka suka berperang, dan perang antar suku sering kali terjadi. Peperangan itu terjadi tidak lain adalah didasari atas fanatisme kesukuan dan keinginan menunjukkan kehebatan masing-masing suku. Sikap dan tabiat ini nampaknya telah mendarah daging dalam diri masyarakat Arab pra Islam.

Dengan kebiasaan bangsa Arab pra Islam yang selalu berperang, maka kesempurnaan fisik adalah sebuah hal yang mutlak diperlukan. Hal tersebut berdampak pada tolok ukur mereka dalam menilai seseorang, di mana seorang dengan tubuh yang sempurna, tegap, dan kuat adalah orang yang hebat. Sebaliknya, orang-orang dengan kecacatan fisik seperti buta, tuli, bisu, dan pincang adalah termasuk golongan yang rendah dan hina. Penyandang cacat dipandang sebelah mata dan tidak memiliki kedudukan di tengah masyarakat.

Demikian pula dalam agama-agama pra Islam di Arab, kecacatan fisik dianggap sebagai karena akibat perbuatan dosa dan kerasukan roh-roh jahat. Kitab Matius misalnya, menyebutkan bahwa Yesus sanggup menyembuhkan orang lumpuh. Kelumpuhan adalah kondisi penuh dosa, sehingga ketika dosa telah diampuni penderita lumpuh akan sembuh. ${ }^{36}$

Berdasarkan pendangan masyarakat Arab pra Islam terhadap keadaan para penyandang

\footnotetext{
${ }^{35}$ Kabilah (clan) adalah suatu organisasi dan identitas sosial masyarakat Arab, baik yang nomadik maupun menetap, yang beranggotakan gabungan dari beberapa keluarga. Muhammad Mushtafâ al-A'zhâmî, The History of The Qur'anic TextFrom Revelation to Compilation, terj. Sohirin Solihin dkk. (Jakarta: Gema Insani, 2005), 19; Lihat Ahmad Jamin, "Kondisi Masyarakat Arab Pra Islam", Jurnal at-Ta'lim 11, no. 2 (2012): 215; Lihat juga Rhoma Dwi Aria Yuliantri, "Historiografi Islam, dalam slide Historiografi Pendidikan Sejarah", sumber dari http://staff.uny.ac.id diunduh pada tanggal 8 April 2017.

${ }^{36}$ Nur Kholis Setiawan, 78-79; Lihat Kitab Matius 9:6, Markus 2: 9, Lukas 5: 24 dan Kisah Para Rasul 9: 33, dalam Aplikasi alKitab terbitan Beblia diunduh para 9 April 2017.
} 
cacat itulah kemudian Allah menggunakan term-term yang menunjukkan makna penyandang cacat untuk mendenotasi orangorang yang kafir, musyrik, dan tidak taat. Adapun tujuannya adalah untuk menunjukkan kehinaan keadaan mereka dan betapa Allah sangat membenci perilaku mereka.

\section{Konotasi netral (cacat fisik)}

Beberapa tempat dalam ayat al-Qur'an yang memuat term-term penyandang cacat juga menunjukkan konotasi yang netral, dalam artian term tersebut memang menunjukkan makna cacat fisik sesungguhnya yang terdapat pada 5 (lima), yaitu 'Abasa (K. 240) [80]: 2, Âli 'Imrân (M.3) [3]: 49, al-Nûr (M.17) [24]: 61, al-Fath (M.26) [48]: 17 dan al- Mâidah (M.27) [5]: 110.

Dengan demikian, penggunaan termterm penyandang cacat dalam al-Qur'an yang menunjukkan makna cacat fisik hanya sekitar $13,15 \%$ saja dari jumlah 38 ayat atau sekitar $0,08 \%$ dari keseluruhan ayat al-Qur'an. Jumlah ini relatif kecil jika dibandingkan dengan jumlah ayat-ayat dengan konotasi cacat teologis, yaitu 33 ayat atau sekitar $86,84 \%$ dari jumlah 38 ayat dan sekitar 1,01\% dari keseluruhan ayat al-Qur'an.

Kemudian, perbandingan surat Makkiyah dan Madaniyah, hanya ada satu ayat Makkiyah yang menunjukkan kecacatan fisik, yaitu surat 'Abasa (K.240) [80]: 2, sedangkan 25 ayat Makkiyah lainnya menunjukkan konotasi kecacatan teologis. Hal ini dapat dipahami bahwa lebih dominannya konotasi kecacatan teologis dalam ayat-ayat Makkiyah sebagai implikasi dari keadaan agama Islam saat periode Makkah.

Sebagaimana catatan sejarah, di mana dakwah Islam masih dalam tahap yang masih awal dan belum berkembang, bahkan cenderung sulit akibat kuatnya penolakan bahkan embargo dari masyarakat Makkah saat itu yang tenggelam dalam lumpur kemusyrikan dan deklinasi yang luar biasa. ${ }^{37}$ Maka untuk membantah perilaku mereka yang tidak menerima kebenaran dan mendawamkan kebatilan, Allah mendenotasi mereka dengan sebutan-sebutan cacat. Selain itu, ayat-ayat tersebut juga dimaksudkan agar mereka mempergunakan akal pikiran serta membuang taklid yang tidak berdasarkan pengetahuan dan dalil-dalil dari tradisi-tradisi nenek moyang. ${ }^{38}$

Berkenaan dengan minimnya ayat-ayat yang berbicara mengenai para penyandang cacat fisik pada ayat-ayat periode Makkah, dapat dipahami bahwa pada saat itu pembahasan mengenai hal itu bukanlah menjadi suatu yang utama. Sebab prioritas dakwah Rasul Saw. saat itu adalah dalam tatanan penanaman akidah tauhid dan belum masuk pada ranah sosial. ${ }^{39}$ Meskipun demikian, adanya satu ayat yang membicarakan penyandang cacat menunjukkan bahwa segmen ini tetap menjadi perhatian. Mengingat kondisi sosial masyarakat Makkah saat itu yang berada pada puncak dekadensi moral. Mereka terbiasa mencela orang-orang yang dianggap lemah dan rendah seperti orang-orang miskin, budak, perempuan, tidak terkecuali dengan para penyandang cacat. ${ }^{40}$

Di lain sisi, terdapat empat surat Madaniyah yang menunjukkan konotasi cacat fisik, dan lima surat lainnya menunjukkan konotasi cacat teologis. Secara persentase, jumlah antara masing-masing konotasi dapat dikatakan hampir seimbang, meskipun tetap lebih banyak ayat yang menunjukkan konotasi negatif. Hal ini dapat dipahami bahwa pada periode Madinah, Allah menginginkan agar

\footnotetext{
${ }^{37}$ Muhammad Abû Syuhbah, al-Madkhâal li Dirâsah al-Qur'ân al-Karîm (Riyâdh: Dâr al- Liwa', 1987), 228.

${ }^{38}$ Tim FKI RADEN, al-Qur'an Kita; Studi Ilmu, Sejarah dan Tafsir Kalamullah (Lirboyo: Lirboyo Press. 2015), hlm. 146.

${ }^{39}$ Hamim Hafiddin, "Pendidikan Islam pada Masa Rasulullah", Jurnal Tarbiya: 3.

40Ati Solehuddin, "Perkembangan Dakwah Nabi Muhammad SAW", Jurnal Islamica 2, no. 2 (2015). Diakses melalui http:// stai-siliwangi.ac.id pada tanggal 9 April 2017.
} 
umat Islam memperhatikan keberadaan para penyandang cacat. Dakwah Rasul SAW pada periode ini lebih menekankan pada syariat secara detail dan hukum-hukum amaliah dalam beribadah dan bermasyarakat. ${ }^{41}$

Pada periode ini, Islam concern membangun sistem peradaban sosial yang kuat dengan menjunjung nilai-nilai syariat. Hal ini disebabkan kehidupan umat Islam di Madinah telah menampakkan keberadaannya, sehingga memiliki kekuatan dan kekuasaan. Sudah menjadi keniscayaan, bahwa kelompok masyarakat ketika sudah terikat dalam satu ikatan, maka membutuhkan undang-undang yang menjamin kebutuhan mereka dalam pranata sosial.

Meskipun demikian, tetap saja pada periode Madinah, ayat-ayat yang memuat term-term penyandang cacat lebih banyak merujuk pada makna kecacatan iman. Ini tidak lain disebabkan pada masa itu perilaku-perilaku yang menyimpang masih saja dipraktikkan oleh orang-orang saat itu. Terutama dalam menjelaskan terhadap kesesatan orang-orang munafik dan keburukan tingkah laku mereka serta bagaimana watak dan tujuan mereka yang berorientasi pada hal-hal duniawi, karena memang komposisi penduduk Madinah saat itu juga ada yang berasal dari Yahudi serta banyak orang yang munafik. ${ }^{42}$ Sebab itulah Allah tetap menggunakan sebutan-sebutan cacat pada mereka, seperti terdapat dalam surat-surat yang banyak bercerita tentang keadaan orang-orang munafik, seperti surat al-Baqarah, surat Âli 'Imrân, dan al- Taubah.

\section{Kelompok Difabel dalam Pandangan al-Qur'an}

Adanya ayat-ayat al-Qur'an yang secara eksplisit menyebutkan term-term penyandang cacat menunjukkan bahwa secara umum al-Qur'an mengakui keberadaan kelompok tersebut, baik

\footnotetext{
${ }^{41}$ Muhammad Abû Syuhbah, 231.

${ }^{42}$ Tim FKI RADEN, 149
}

cacat fisik maupun cacat non fisik (teologisnya).

Keberadaan penyandang cacat fisik dalam ayat-ayat al-Qur'an yang relatif sedikit jumlahnya tidak lain disebabkan Islam memandang netral terhadap penyandang cacat fisik, dengan artian sepenuhnya menyamakan para penyandang cacat sebagaimana manusia lainnya. Islam sendiri lebih menekankan pengembangan karakter dan amal shaleh, daripada melihat persoalan fisik seseorang. Dengan kata lain, kesempurnaan fisik bukanlah menjadi hal yang prioritas dalam hal pengabdian diri kepada Allah, melainkan kebersihan hati dan kekuatan iman kepada-Nya. Hal ini dipertegas dalam sebuah sabda Rasul SAW yang diriwayatkan oleh Imam Muslim dan Ibnu Mâjah melalui jalur sahabat Abû Hurairah r.a:

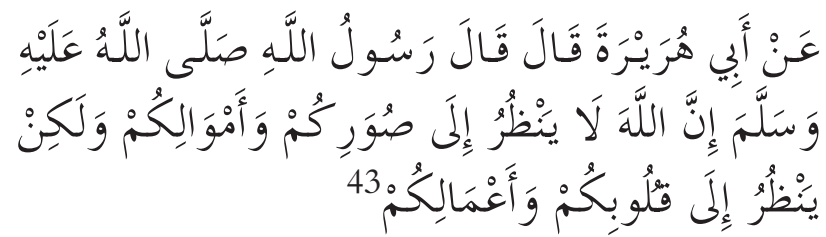

"Dari Abu Hurairah berkata, Rasulullah SAW

bersabda: Sesungguhnya Allah tidak melihat

kepada bentuk rupa dan hartamu, akan tetapi

Dia melihat pada hati dan amalmu”.

Begitulah Islam lebih menekankan pentingnya amal atau perbuatan-perbuatan baik. Hal ini bisa dimaklumi, karena Islam sendiri merupakan kesatuan antara amal dan iman yang tidak bisa dilepaskan.

Selain itu, dalam khazanah kajian-kajian ilmu keislaman, khususnya tafsir al-Qur'an, selama ini belum tampak perhatian khusus terkait persoalan penyandang cacat ini. Faktor yang menyebabkan minimnya kajian mengenai persoalan ini boleh jadi disebabkan minimnya pengkaji atau penafsir yang muncul dari kalangan penyandang cacat itu sendiri. Sebagaimana dalam kajian keilmuan klasik lain, seperti dalam bidang akidah, tasawuf,

\footnotetext{
${ }^{43}$ Muslim bin al-Hajjâj al-Nasisaburî, Shahîh Muslim, jilid 12, hadis nomor 4651 dalam Bab Tahrîm Zhalama al-Muslim wa Khadzalahu, al-Maktabah al-Syâmilah, 427; Lihat juga Abû Abdillâh bin Yazîd bin Mâjah, Sunan Ibnu Mâjah, jilid. 12, hadis nomor 4133 dalam Bab Qana'ah, alMaktabah al-Syâmilah, 173.
} 
filsafat, maupun hadis. Hal ini sebanding dengan adanya kajian ulama klasik mengenai perempuan yang oleh sebagian kelompok dinilai banyak menunjukkan adanya bias atau terkesan mendiskriminasikan. ${ }^{44}$ Tentu saja persoalan ini dikarenakan pengkaji atau penafsir perempuan sangatlah jarang ditemukan dalam sejarah Islam, terutama sepeninggal Nabi Muhammad SAW.

Terlepas daripada itu semua, menjadi sebuah kenyataan bahwa penyandang cacat merupakan bagian dari komposisi kehidupan manusia, dan al-Qur'an mengakomodasi keberadaannya. Para ulama terdahulu dalam karya-karya mereka telah memberikan embrio bagi kajian lebih lanjut mengenai keberadaan kelompok ini, terutama ketika memberikan syarahan ayat-ayat dengan term-term penyandang cacat dalam al-Qur'an.

Jika diperhatikan ayat-ayat al-Qur'an yang berbicara mengenai penyandang cacat fisik, ditemui bahwa ayat-ayat tersebut justru merujuk pada makna perlindungan dan pengayoman. Surat 'Abasa [80]: 1-2 misalnya, secara umum berisi teguran atas sikap Rasul Saw. yang tidak ramah terhadap seorang penyandang cacat yang datang padanya ${ }^{45}$

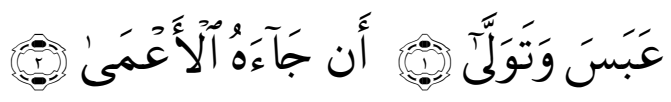

"Dia (Muhammad) bermuka masam dan berpaling. Karena telah datang seorang buta kepadanya".

Mayoritas ulama tafsir menjelaskan bahwa ayat ini turun berkenaan dengan kedatangan seorang buta (tunanetra), bernama 'Abdullâh bin Ummi Maktûm kepada Rasulullah Saw. menyela pembicaarannya untuk mendapatkan keterangan tentang agama Islam, sedangkan saat

\footnotetext{
${ }^{44}$ Pendapat mengenai diskriminasi terhadap kaum perempuan dan upaya mengeluarkan mereka dari kondisi tersebut selanjutnya disebut sebagai paham feminisme. Lihat Henri Shalahuddin, al-Qur'an Dihujat (Jakarta: al-Qalam, 2007), 50.

${ }^{45}$ Abû al-Fidâ' Ismâil bin Katsîr, Tafsîr al- Qur'ân al'Azhîm, jilid 8 (T.tp: Dâr al-Thayyibah, 1999);lihat juga Muhammad bin Ahmad Abî Bakr al-Qurthubî, al-Jâmi' li Ahkâm al-Qur'ân (Beirut: al-Risâlah, 2006), 69.
}

itu Rasulullah Saw. tengah sibuk menerima tamu para pembesar Quraisy - menurut alZamakhsyarî, di antara pembesar Quraisy yang hadir saat itu adalah 'Utbah dan Syibah bin Rabî'ah, Abû Jahal bin Hisyâm, 'Abbâs bin 'Abdul Muthallib, Umayyah bin Khalaf dan al Walîd bin al Mughîrah ${ }^{46}$ - dengan harapan mereka akan mendapatkan hidayah dan memeluk agama Islam. Dalam keadaan demikian, kontan saja Rasul Saw. menunjukkan sikap acuh dan mimik yang masam. Sehingga turunlah ayat ini untuk menegur sikap Rasul Saw. tersebut. ${ }^{47}$

Teguran dalam ayat di atas bisa dikaitkan dengan larangan mengabaikan orang yang tekun beribadah kepada Allah meskipun orang tersebut tidak memiliki pangkat atau derajat sosial yang tinggi. Sebagaimana telah diungkapkan di awal, ayat tersebut diturunkan ketika beberapa pembesar Quraisy mendatangi Rasul yang pada saat itu di sekelilingnya ada beberapa orang yang tidak memiliki status sosial. Pembesar Quraisy menyarankan kepada Rasul agar orang-orang tersebut menyingkir karena kedatangan para pembesar. Para pembesar Quraisy itu berkilah bahwa mereka akan mengikuti ajaran Rasul jika permintaannya dipenuhi, karena orang di sekeliling Rasul adalah orang-orang yang dianggap kecil, sehingga para pembesar tersebut merasa tidak pantas bersanding dengan mereka di hadapan Rasul.

Adanya teguran dari Allah SWT dalam beberapa tempat dalam al-Qur'an, termasuk dalam surat 'Abasa [80]: 2 merupakan salah satu bukti kebenaran dan keorosinilan al- Qur'an. Sebuah bukti bahwa al- Qur'an bukanlah

\footnotetext{
${ }^{46}$ Abû al-Qâsim Mahmûd al-Zamakhsyarî, al-Kasysyâf 'an Haqâiq Ghawâmidh al- Tanzîl wa 'Uyûn al-Aqâwîl fî Wujûh alTa'wîl, jilid 6 (Riyadh: Maktabah al- 'Abîkân, 1998), 313.

${ }^{47}$ Jalâl al-Dîn al-Suyuthî, al-Durr al-Mantsûr, jilid 8 (Beirut: Dâr al Fikr, t.th), 416 (dengan riwayat dari Âisyah r.a); Muhammad bin Ahmad Abî Bakr al-Qurthubî, 69 (dari jalur periwayatan Mâlik bin Anas dari Hisyâm bin 'Urwah); Abû al- Fidâ' Ismâil bin Katsîr, 319 (dengan jalur periwayatan al-Hâfizh Abû Ya'lâ dari Anas bin Mâlik); Lihat juga Wahbah al-Zuhailî, Tafsîr al-Munî, jilid 15 (Beirut: Dar al-Fikr, 2003), 428 (dari jalur periwayatan al- Tirmidzî dari 'Âisyah r.a).
} 
karangan Muhammad Saw, karena jika demikian niscaya akan ia sembunyikan teguran dan kritik tersebut. $^{48}$

Secara sosiologis, sebab ayat yang demikian dapat dipahami sebagai ketidaksiapan mental para pembesar Quraisy terhadap kesetaraan yang diajarkan oleh Islam. Karena ayat ini menjadi dasar tentang ajaran Islam yang menjunjung kesetaraan dengan tidak memandang tinggi rendahnya status sosial, baik laki-laki maupun perempuan. ${ }^{49}$

Meski perlu digarisbawahi bahwa permintaan pembesar Quraisy tersebut belum tentu menjadi syarat mutlak bahwa mereka akan memeluk agama Islam. Dengan demikian, ayat ini bisa juga dipahami berada dalam konteks antisipatif agar Rasul Saw. tidak mudah percaya, apalagi sampai terpedaya dengan janji pembesar Quraisy yang belum terbukti kebenarannya.

Di sisi lain, ayat ini memberikan dukungan moral serta tanggung jawab kepada Rasul Saw. agar tidak mengabaikan kelompok masyarakat yang dianggap memiliki strata sosial rendah. Lebih dari itu, kesahajaan dan perhatian Rasul Saw. terhadap wong cilik sejatinya merupakan sikap arif serta keteladanan yang menjadi pegangan dan panutan bagi pemimpin masyarakat.

Selain itu, teguran atas tindakan Nabi Saw. yang berpaling dan menunjukkan ekspresi tidak senang juga memiliki hikmah besar, di antaranya adalah untuk membesarkan hati para penyandang cacat, dan orang-orang yang terbatas lainnya seperti fakir dan miskin. Dengan teguran ini tentu menunjukkan bahwa kedudukan berdasarkan materi tidak selamanya baik, boleh jadi seorang dengan segala keterbatasannya memiliki kedudukan yang lebih mulia di sisi Allah SWT. ${ }^{50}$

Lebih lanjut, ayat ini dengan jelas menunjukkan

\footnotetext{
${ }^{48}$ Ahmad Zaki Mubarok, "Studi Tentang Historitas al Qur'an: Telaah pemikiran M.M. Azami dalam The History of

The Qur'anic Tekxt From Revelation to Compilation", Jurnal Hermeneutik 9, no.1 (2015): 7.

${ }^{49}$ Wahbah al-Zuhaili, 430.

${ }^{50}$ Ibid.
}

atas hukum wajib bagi adanya kesamaan (al musâwamah) dalam Islam, terutama dalam hal memberi penyampaian dakwah dan peringatanperingatan agama tanpa membeda-bedakan strata sosialnya, miskin atau kaya, cacat ataupun tidak.

Dengan demikian, pengayoman yang dimaksudkan oleh ayat-ayat berkenaan dengan penyandang cacat fisik dalam al-Qur'an tersebut dapat dikatakan sebagai upaya mendobrak dan merekonstruksi stigma negatif masyarakat pada waktu itu. Lebih dari itu, al-Qur'an datang untuk membebaskan para mustadh'afîn (kelompok marjinal) dari keterhinaan. Kesemuanya itu tidak hanya sebatas teori yang mengawang-awang, melainkan telah dibuktikan dalam bentuk praktis dan membumi oleh Rasul Saw.

Perhatikan bagaimana Rasul Saw. memberikan kesempatan dan posisi cukup strategis kepada salah seorang sahabatnya yang menyandang kecacatan, yaitu 'Abdullâh bin Ummi Maktûm sebagai salah seorang muadzin, selain dari Bilâl bin Rabbah. Berdasarkan riwayat dari Imam Abû Dâud yang bersumber dari 'Âisyah r.a:

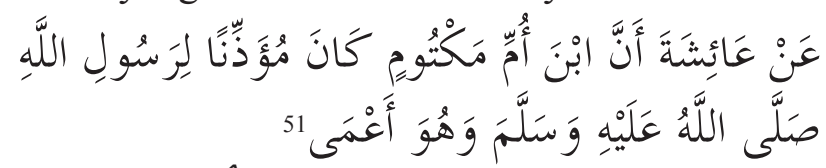

"Dari 'Âisyah: Sesungguhnya Ibnu Ummi Maktûm adalah seorang muadzin Rasulullah Saw., dan dia adalah seorang tunanetra".

Dengan demikian, dalil-dalil di atas menjadi legitimasi fakta bahwa secara doktrin, Islam tidak mengenal perbedaan status sosial serta tidak mengenal perbedaan perlakuan terhadap kaum difabel. Islam memandang umatnya untuk berkontribusi dalam kehidupannya secara proporsional. Hal ini telah dibuktikan oleh Rasul dengan memberikan kepercayaan dan posisi yang cukup strategis kepada sahabatnya yang sebelumnya dianggap rendah, seperti Bilâl bin Rabbah dari kalangan budak dan Abdullâh bin

${ }^{51}$ Abû Dâud Sulaiman bin al-Asy'ats al-Sijistanî, Sunân Ab̂̂ Dâud, juz 2, nomor hadis 450 dalam Bab al-Adzân li alA'mâ, al-Maktabah al-Syâmilah, 136. 
Ummi Maktûm dari kelompok cacat sebagai muadzin. Tentu saja yang demikian itu sangat jauh berbeda dengan kebiasaan masyarakat Arab sebelumnya.

Penting untuk digarisbawahi bahwa kelompok difabel bukanlah kelompok yang mesti dimarjinalkan, apalagi dianggap sebagai kutukan serta pembawa aib dalam keluarga dan masyarakat. Jika masyarakat Arab Jahiliyah menempatkan kelompok difabel dalam status rendah, disebabkan persepsi bahwa kesempurnaan fisik sebagai hal utama guna mempertahankan ego dan kehormatan suku tertentu.

Perlindungan terhadap kaum difabel juga diperlihatkan oleh al-Qur'an dalam ayat lainnya, seperti surat al Fath [48]: 17:

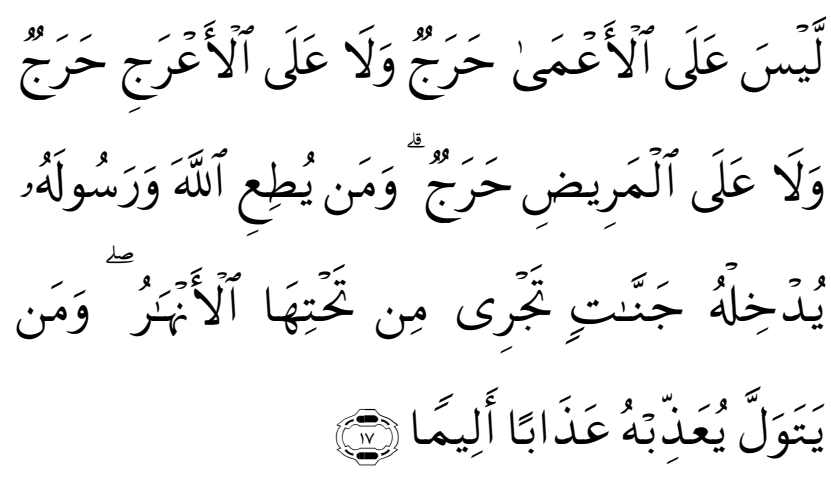

"Tiada dosa atas orang-orang yang buta dan atas orang-orang yang pincang dan atas orang-orang yang sakit (apabila tidak ikut berperang). Dan barangsiapa yang taat kepada Allah dan Rasul-Nya, niscaya Allah akan memasukkannya ke dalam surga yang mengalir di bawahnya sungai-sungai, dan barang siapa yang berpaling niscaya akan di azab-Nya dengan azab yang pedih".

Ayat ini turun berkenaan dengan keresahan orang-orang yang memiliki keterbatasan fisik, baik karena cacat fisik maupun karena sakit, dalam melaksanakan perintah berjihad yang sesungguhnya diarahkan kepada orang munafik yang enggan berjuang, meskipun kondisi fisik mereka sangat memungkinkan. Karena adanya ancaman al-Qur'an terhadap kelompok yang tidak mau berjuang dan berjihad di jalan Allah, sekelompok orang yang secara fisik memiliki keterbatasan merasa resah, lalu mengadu kepada Rasulullah Saw, langkah terbaik apa yang seharusnya mereka ambil. Dengan keresahan ini maka turunlah surat al-Fath ayat $17 .{ }^{52}$

Ayat di atas bisa dipahami bahwa pada prinsipnya al-Qur'an memberikan perlakuan khusus terhadap orang yang meskipun secara fisik terbatas, tetapi mereka memiliki lahan beribadah serta kontribusi aktivitas sosial yang luas serta dapat memberikan kemanfaatan terhadap orang banyak. Ayat ini juga menjadi indikator penghargaan Islam terhadap kelompok yang memiliki keterbatasan fisik. Kemampuan seseorang tidak bisa diukur dengan kesempurnaan fisik, melainkan banyak faktor lain yang turut menentukan. Oleh karena itu, tidak ada pijakan teologis maupun normatif dalam Islam untuk mentolelir tindakan diskriminatif terhadap siapapun, termasuk para penyandang difabel.

Dalam bahasa al-Qur'an, ketakwaan yang menjadi tolok ukur kemuliaan seseorang, lepas dari status sosial, kesempurnaan fisik, warna kulit, ras serta kebangsaan seseorang. Ayat tersebut memberi legitimasi akan prinsip kesetaraan yang diajarkan Islam untuk menjauhkan diri dari sistem kelas atau strata sosial lainnya. Dengan demikian, kelompok difabel secara sosial diakui keberadaannya oleh Islam sebagai bagian dari umat secara umum, serta mereka memiliki hak dan kewajiban yang sama sesama muslim.

Dengan demikian, beberapa ayat di atas dapat dijadikan pijakan untuk menolak anggapan sebagian masyarakat bahwa penyandang cacat adalah kutukan, pembawa aib serta abnormalitas yang diakibatkan oleh hal-hal yang tidak rasional. Sebaliknya, difabel merupakan bagian dari takdir seseorang yang tidak seorangpun mampu mengelak darinya. Dalam konteks ini, al-Qur'an merupakan rujukan bagi spirit perlindungan Islam terhadap kaum difabel.

\footnotetext{
${ }^{52}$ Imam al-Suyuthî menukil riwayat al- Thabaranî dari jalur Zaid bin Tsâbit, lihat Jalâl al-Dîn al-Suyuthî, 521. Sedangkan Wahbah al-Zuhaili menukil riwayat yang bersumber dari Ibnu 'Abbâs, lihat Wahbah al-Zuhailî, Tafsîr al Munîr, jilid 13, 495.
} 


\section{Kesimpulan}

Berdasarkan pemaparan di atas, nampak bahwa ayat-ayat yang di dalamnya terdapat termterm difabel kebanyakan menunjukkan konotasi negatif, di mana term-term difabel digunakan untuk merendahkan seseorang. Namun, difabel yang dimaksud bukanlah difabel dalam arti yang dipahami pada umumnya yang berupa kecacatan fisik maupun non fisik, melainkan mereka yang cacat teologisnya. Meskipun secara fisik panca indra mereka berfungsi dengan baik, namun yang menjadi value adalah kemampuan panca indra itu mengambil manfaat yang bermuara pada tauhidullâh.

Sedangkan beberapa ayat yang menunjukkan pada konotasi netral, merujuk pada kelompok difabel dengan kekurangan fisik. Semua ayat dengan konotasi kedua ini menunjukkan pada perlindungan dan pembelaan bagi difabel. Tidak ada satupun sumber-sumber informasi syar'i yang membenarkan perlakuan diskriminatif bagi kelompok ini, dengan kata lain, alQur'an meniadakan stereotip dan mendorong pemberdayaan kelompok difabel. Dengan adanya sikap ramah dan pemberdayaan bagi kelompok difabel diharapkan akan menciptakan kemandirian dan terpenuhinya hak-hak kesamaan bagi mereka. Karena fakta membuktikan bahwa sudah banyak penyandang difabel yang mampu mencapai prestasi yang tidak kalah dengan orangorang yang fisiknya sempurna.

\section{Daftar Kepustakaan}

al-A'zhâmî, Muhammad Mushtafâ. The History of The Qur'anic Text-From Revelation to Compilation. Terj. Sohirin Solihin dkk. Jakarta: Gema Insani. 2005.

Ahmad Jamin. "Kondisi Masyarakat Arab Pra Islam”. Jurnal at-Ta'lim 11, no. 2 (2012).

Ahmad Warson Munawir. Kamus al-Munawwir. Surabaya: Pustaka Progresif. 2002.
Ahmad Zaki Mubarok. "Studi Tentang Historitas al-Qur'an: Telaah pemikiran M.M. Azami dalam The History of The Qur'anic Tekxt From Revelation to Compilation". Jurnal Hermeneutik 9, no.1, (2015).

Akhmad Sholeh. "Islam dan Penyandang Disabilitas: Telaah Hak Aksesibilitas Penyandang Disabilitas dalam Sistem Pendidikan di Indonesia". Jurnal PALASTREN 8, no. 2 (2015).

Aplikasi al-Kitab terbitan Beblia diunduh para 9 April 2017.

Ati Solehuddin. "Perkembangan Dakwah Nabi Muhammad SAW. Jurnal Islamica 2, no. 2 (2015). Diakses melalui http://staisiliwangi.ac.id pada tanggal 9 April 2017.

Ayat Aplikasi al-Qur'an Digital versi 1.3.4.

al-Bâqi, Muhammad Fuad 'Abd. al Mu'jam al Mufahras li Alfâzh al-Qur'ân al-Karîm. Kairo: Dâr al-Hadîts. 1364 H.

Departemen Agama RI. Al-Qur'an dan Terjemahnya. Semarang: PT. Toha Putra. 1999.

Dewi Pandji. Sudahkah Kita Ramah Pada Anak Special Needs?. Jakarta: PT Elex Media Komputindo. 2013.

al-Dimasqî, Abû al-Fidâ' Ismâîl bin 'Amr bin Katsîr al-Qurasyî. Tafsîr al-Qur'ân al'Azhîm. T.tp: Dar Thayibah li al-Nasyr wa al-Tauzi': 1999.

FKI Ahla Sufah. Al-Qur'an Kita: Studi Ilmu, Sejarah dan Tafsir Kalamullah. Lirboyo: Lirboyo Press. 2011.

Frieda Mangunsong. Psikologi dan Pendidikan Anak Berkebutuhan Khusus. Jilid 1dan II. Depok: LPSP3 UI, 2011.

Hamim Hafiddin. "Pendidikan Islam pada Masa Rasulullah". Jurnal Tarbiya.

Henri Shalahuddin. Al-Qur'an Dihujat. Jakarta: al-Qalam. 2007. 
http://m.liputan6.com diakses pada 25 Juli 2016.

http://Poskota News.com diakses pada 25 Juli 2016.

Husamah. A to Z Kamus Psikologi Super Lengkap. Yogyakarta: Andi Offset. 2015.

Ibnu Mâjah, Abû Abdillâh bin Yazîd. Sunan Ibnu Mâjah. Al- Maktabah al-Syâmilah.

Ibnu Mazhûr. Lisân al- 'Arab. jilid 4 dan 5. Beirut: Dâr Shâdir. 2010.

Kadar M Yusuf. "Indera Manusia Menurut al-Qur'an dan Psikologi; Suatu Kajian Perbandingan”. Laporan Penelitian: Universitas Negeri Sultan Syarif Kasim Riau, 2003.

Mansour Fakih. Kesetaraan Hak Penyandang Cacat. Yogyakarta: Kaukaba. 2004.

MPR RI. Undang-Undang Dasar Negara Republik Indonesia Tahun 1945. Sekretariat Jendral Majelis Permusyawaratan Rakyat Republik Indonesia (MPR RI). Cet. XV.

al-Naisaburî, Muslim bin al-Hajjâj. Shahîh Muslim. Al-Maktabah al-Syâmilah.

al-Nasâî, Ahmad bin Syu'aib bin 'Alî bin Sinân. Sunân al-Nasâî. Al-Maktabah alSyâmilah.

Nur Faizin. Sepuluh Tema Kontroversial 'Ulum al-Qur'an. Kediri: CV Azhar Risalah. 2011.

Nur Khalis Setiawan. Pribumisasi al- Qur'an. Yogyakarta: Kaukaba. 2012.

Pusat Bahasa. Kamus Bahasa Indonesia. Jakarta: DEPDIKNAS. 2008.
al-Qurthubî, Muhammad bin Ahmad Abî Bakr. Al-Jâmi' li Ahkâm al-Qur'ân. Beirut: alRisâlah, 2006.

Rhoma Dwi Aria Yuliantri. "Historiografi Islam”. Dalam slide Historiografi Pendidikan Sejarah. sumber dari http://staff.uny.ac.id diunduh pada tanggal 8 April 2017.

al-Sijistanî, Abû Dâud Sulaiman bin al-Asy'ats. Sunân Abû Dâud. Al-Maktabah al-Syâmilah.

al-Shâlih, Muslih. Qâmûs Musthalahât al- 'Ulum al- Ijtimâ'iyah Injilizî wa al- 'Arabî. Riyâdh: Dâr al-'Alam al-Kutub. 1419 H.

al-Suyuthî, Jalâl al-Dîn. Al-Itqân fì 'Ulûm alQur'ân. jilid I. Beirut: Dar al Fikr, T.th.

-------. al Durr al Mantsûr. Jilid 5, 6, dan 8. Beirut: Dâr al-Fikr. T.th.

Syalabi, Ahmad. Sejarah Kebudayaan Islam. Jilid. I. Jakarta: al-Husna Zikra. 197.

Syuhbah, Muhammad Abû. Al-Madkhal li Dirâsah al-Qur'ân al-Karîm. Riyâdh: Dâr al- Liwa'. 1987.

al-Thabarî, Ibnu Jarîr. Jâmi' al-Bayân 'an Ta'wîl ay al-Qur'ân. Jilid, 11, 12, 15, 17, 19, dan 20. T.tp: al-Risâlah: 2000 .

Tim FKI RADEN. Al-Qur'an Kita; Studi Ilmu, Sejarah dan Tafsir Kalamullah. Lirboyo: Lirboyo Press. 2015.

al-Zamakhsyarî, Abûal-Qâsim Mahmûd. Al-Kasysyâf 'an Haqâiq Ghawâmidh al-Tanzîl wa 'Uyûn al-Aqâwîlfî Wujûh al-Ta'wîl. Jilid. 2, 4, dan 6. Riyadh: Maktabah al-'Abîkân. 1998.

al-Zuhaili, Wahbah. Tafsîr al-Munîr. Beirut: Dar al-Fikr. 2003. 